AJHSE Vol: 2 (2): 25-35 2021

DOI: 10.52417/ajhse.v2i2.153

Accepted Date: Sept.30, 2021

(C) 2021. CC License 4.0

www.ajhse.org

CrossMark

$\leftarrow$ click for updates
African Journal of Health, Safety and Environment

An official publication of the

Applied Environmental Bioscience and Public Health Research Group

University of Benin, Benin City, Nigeria

Open Access | Bi-annual | Peer-reviewed | International

ISSN (Online): 2695-1819 | ISSN (Print): 2695-2386

\title{
IDENTIFICATION OF FUNGI ISOLATED FROM BATHROOMS IN FEMALE STUDENTS' HOSTEL, UNIVERSITY OF BENIN, BENIN CITY
}

\author{
*1Ozoaduche, C.L. \& ${ }^{2}$ Idemudia, I.B.
}

${ }^{*}$ Department of Microbiology, Faculty of Life Sciences, University of Benin, Benin City, Edo State, Nigeria.

*Corresponding Author's E-mail:chiomalilian01@gmail.com Phone: +2348162011473

\begin{abstract}
$\mathrm{F}$

Jungi are specifically dangerous as they exhibit a significant tolerance to environmental changes and can proliferate under low relative humidity, unlike bacteria. They produce spores that are easily dispersed by air hence they are ubiquitous. The study aimed at identifying the fungal isolates present in the bathrooms located on the three floors of the hostel, University of Benin, Benin City. Samples were collected from the walls of the bathrooms using sterile swab sticks and were identified using standard microbiological techniques. The isolated fungi were Aspergillus nidulans, A. niger, A. tamarii, A. flavus, Candida albicans, Penicillium cyclopium, P. oxalicum, Mucor mисеdo, Trichophyton rubrum and Rhodotorula species. From the ground floor bathrooms, Candida albicans (23.40\%) were most frequently isolated, Aspergillus nidulans (55.56\%) were mostly isolated from the first floor and Мисо тисеdo (56.00\%) were the most isolated from the second floor. After washing the bathrooms, Mисог mисеdo was scarcely isolated from the walls of the bathrooms. The findings were processed statistically using the two-tailed test to detect the significant difference between the groups of means for the fungal counts from each floor. A significant difference $(\mathrm{p}<0.05)$ in the fungi isolated before and after washing was found. Isolated fungi from this study are known to be of public health importance hence, strict hygiene practices should be observed by those using the bathrooms.
\end{abstract}

Keywords: Bathroom, Fungi, Hostel, Identification, Isolates

LICENSE: This article by African Journal of Health, Safety and Environment (AJHSE)is licensed and published under the Creative Commons Attribution License 4.0 International License, which permits unrestricted use, distribution, and reproduction in any medium, provided this article is duly cited.

COPYRIGHT: The Author(s) completely retain the copyright of this published article.

OPEN ACCESS: The Author(s) approves that this article remains permanently online in the open access (OA) model

QA:This Article is published in line with"COPE (Committee on Publication Ethics) and PIE (Publication Integrity \& Ethics)”. 


\section{INTRODUCTION}

Fungi are eukaryotic heterotrophs, that extensively include species of moulds, yeasts and mushrooms. They could be single celled (yeasts) or multicellular (moulds) and may also be classified as biotrophs, saprotrophs or necrotrophs which reproduce and disperse by spore formation (Carris et al., 2012; Bueno and Silva, 2014). Fungi proliferate in humid environments composed of organic substrate. Moulds are very adaptable and can grow even on damp inorganic materials such as glass, metal, concrete or painted surfaces if a microscopic layer of organic nutrients is available. Such nutrients can be found on household dust and soil particles (Robins and Morell, 2007). Fungi are capable of extracting their food from the organic materials they grow on and the ability to reproduce by way of minute spores makes them ubiquitous (DeHoog et al., 2007). Fungal colonization of buildings is especially common in low-income communities in developing countries, where buildings are situated indiscriminately without consideration for environmental sanitation, urban planning and building regulations (Ahiamba et al, 2008; Ayanbimpe et al, 2010).

Fungi are particularly dangerous because they are able to withstand different conditions of the environment. Moreover, they can survive in environment with low relative humidity (RH) unlike bacteria for their proliferation and formation of spores which are dispersed by wind. The primary reason of contamination in the environment is due to the dispersion of spores and the indoor environment is colonized by moulds through the dispersal of spores within the ventilating system (Jabber et al., 2016). Some pathogenic fungi in soil and vegetation which can induce infections could be transferred by animals or foot wears of humans into their homes (Ayanbimpe et al., 2012).

Occupants of buildings have been reported to develop certain allergies and affected by toxins as a result of the fungal contaminations in indoor environment (Caillaud et al., 2018). Inhalation of fungal spores, fragments (parts), or metabolites (e.g., mycotoxins and volatile organic compounds) from a wide variety of fungi can trigger symptoms of asthma, rhinitis or bronchitis (sick building syndrome) or other building related illnesss (Crook and Burton, 2010). All moulds have the potential to cause health effects such as headaches, breathing difficulties, skin irritation, allergic reaction and aggravation of asthma symptoms (Jabber et al., 2016). The emergence of diseases in the immunecompromised could possibly be triggered by the inhalation of spores of air-borne fungi. Evidence on the association between mould exposure and most human respiratory diseases has been reported (Caillaud et al., 2018). Most people can recognize and react to the mouldy smell negatively with symptoms like headaches, vomiting, nausea, blocked noses, and asthma. Volatile products of indoor moulds have also been suggested to cause toxic illnesses or mycotoxicoses (Sean and Abbott, 2002; Straus and Wilson, 2006). Mycotoxins can be inhaled by people through the air, ingested through food, and can also come in contact with skin, resulting in many illnesses such as gastrointestinal, respiratory, and reproductive disorders (O'connor et al., 2004; Mirabelli et al., 2006). Also reported are eye irritations, poor taste sensations, sore throat and tiredness (U.S. Environmental Protection Agency, 2003). Even severe neurologic conditions such as depression have been linked to indoor mould colonization (Shenassa et al, 2007). The species of Aspergillus, Fusarium and Penicillium are potential toxigenic moulds, hence the awareness of the colonization of such spores on bathrooms' walls and their termination by washing with disinfectants and disinfectants are of public health importance. 


\section{MATERIALS AND METHODS STUDY AREA}

Samples were collected from bathrooms located at the female students' hostel, University of Benin, Benin City, and transported to the Department of Microbiology. Analysis was carried out at University of Benin Microbiology Department Laboratory.

\section{SAMPLE COLLECTION}

Samples were collected from the walls of the hostel's bathrooms using swabs sticks, before and after cleaning of the bathrooms. A total of seventy-two (72) samples were collected from the bathrooms of the three floors at three consecutive times. A solution of $1 \%$ glucose peptone diluents was labeled and used to moisten the swab and about 5 $\mathrm{cm}$ of the bathroom's wall was swabbed systematically in two directions at $90^{\circ}$ to one another while slowly rotating the swab around its long axis. The cotton end was then placed into the diluents bottle and snapped off so that it falls into the $10 \mathrm{ml}$ bijou bottle containing $1 \%$ glucose peptone and transferred to the laboratory and incubated for 24 hours after which a ten-fold serial dilution was carried out on each sample before inoculation (FAO, 2006; Satyada and Sandle, 2016).

\section{PREPARATION AND STERILIZATION OF MEDIA AND MATERIALS}

Potato dextrose agar was prepared according to the manufacturer's instruction. The media and glass wares (e.g test tubes and conical flasks) were sterilized in an autoclave at a temperature of $121^{\circ} \mathrm{C}$ for 15 minutes. The agar media were supplemented with $0.25 \mathrm{mg} / \mathrm{ml}$ chloramphenicol (Odds, 1992).

\section{MICROBIOLOGICAL ANALYSIS INOCULATION}

One millilitre of each diluted sample $\left(10^{-4)}\right.$ was dispensed into empty labeled sterile plates in duplicates. Amended sterile medium (potato dextrose agar supplemented with antibiotics) were poured aseptically into the petri dishes, whirled slowly and left to cool. The agar solidifies and the incubation of the agar plates was done at $28 \pm 2^{\circ} \mathrm{C}$ (room temperature) for $4-7$ days (Cheesebrough, 2006).

\section{ISOLATION OF PURE CULTURE}

After incubation, appearance of discrete, well separated colonies in culture plates were examined for suspected fungal species base on their colonial morphology. Each distinct colony of fungi were sub-cultured into separate potato dextrose agar plate by picking minute number of hyphae or spores onto a non-inoculated solidified agar plate, much rather at the centre of the agar plate so as to support best colonial growth and spore formation of the fungi. The incubation of the plates was done at room temperature $\left(28 \pm 2^{\circ} \mathrm{C}\right)$. Fungal growth (pure culture) were usually seen from three (3) days after incubation (Al-mohanna, 2016). 


\section{DIRECT MICROSCOPY}

The sub-cultured fungi were identified based on their cultural and morphological characteristics such as mycelia, spore type and other fruiting bodies by viewing a lactophenol cotton blue wet mount at $\mathrm{x} 40$ objective lens of a compound microscope and comparing the structures to a fungal atlas. Candida albicans were identified by carrying out germ tube test (Arora et al., 2003; Catherine et al., 2015; Kidd et al., 2016).

\section{ENUMERATION}

\section{Calculation of fungal counts $\left(\mathrm{cfu} / \mathrm{cm}^{2}\right)$}

Count per swab $=\frac{C}{v\left(n_{1}+0.1 n_{2}\right) d} \times n_{3}$

$\mathrm{C}=$ sum of colonies on all plates counted

$\mathrm{v}=$ volume applied to each plate

$\mathrm{n}_{1}=$ number of plates counted at the first dilution

$\mathrm{n}_{2}=$ number of plates counted at the second dilution

$\mathrm{n}_{3}=$ original volume of neat suspension i.e. 10

$\mathrm{d}=$ dilution from which the first count was obtained e.g $10^{-4}$

$\mathrm{CFU} / \mathrm{cm}^{2}=\frac{\text { Count }}{\text { Area swabbed }}$

(PHE, 2017)

Fungal contamination was determined by calculating the occurrence percentage for the isolates (Jabber et al., 2016).

Occurrence Percentage $=\frac{\text { No. of Isolates for genus or type }}{\text { Total isolate number for all fungi }} \times 100$

\section{DATA ANALYSIS}

Data obtained were presented as mean \pm standard error (SE) of duplicate data. Significance difference between different groups was tested with double tailed t-test using SPSS version 20 (Ogbeibu, 2014). The graphs were plotted using Microsoft Excel. 


\section{RESULTS}

\section{FUNGAL COUNTS FROM THE BATHROOMS OF THE THREE FLOORS OF THE HOSTEL}

Table 1 shows a significant reduction in the fungal load of the bathrooms' walls after washing. The ground floor had the highest fungal count, while the first floor had the least fungal count. Before washing of the bathrooms, the fungal count $\left(\mathrm{x} 10^{4} \mathrm{cfu} / \mathrm{cm}^{2}\right)$ ranged between $6.40 \pm 0.04$ and $22.80 \pm 0.30$, while after washing the fungal count $\left(\mathrm{x} 10^{4} \mathrm{cfu} / \mathrm{cm}^{2}\right)$ ranged from $0.00 \pm 0.00$ to $0.80 \pm 0.02$. A significant difference between before and after washing was observed on the first week $(\mathrm{p}=0.049)$, second week $(\mathrm{p}=0.030)$ and third week $(\mathrm{p}=0.048)$ in the hostel.

Table 1: Fungal counts from the bathrooms

\begin{tabular}{lllll}
\hline $\begin{array}{l}\text { Bathrooms' } \\
\text { Location }\end{array}$ & Period & $\begin{array}{l}\text { Week 1 } \\
\mathbf{1 0} \mathbf{4}\left(\mathbf{c f u} / \mathbf{c m}^{2}\right)\end{array}$ & $\begin{array}{l}\text { Week 2 } \\
\mathbf{1 0}^{\mathbf{4}}\left(\mathbf{c f u} / \mathbf{c m}^{\mathbf{2}}\right)\end{array}$ & $\begin{array}{l}\text { Week 3 } \\
\mathbf{1 0}^{\mathbf{4}}\left(\mathbf{c f u} / \mathbf{c m}^{\mathbf{2}}\right)\end{array}$ \\
\hline Ground Floor & Before washing & $18.80 \pm 1.00$ & $14.80 \pm 0.08$ & $22.80 \pm 0.30$ \\
& After washing & $0.80 \pm 0.02$ & $0.20 \pm 0.02$ & $4.40 \pm 0.02$ \\
First Floor & Before washing & $7.20 \pm 0.08$ & $8.00 \pm 0.10$ & $6.40 \pm 0.04$ \\
& After washing & $0.40 \pm 0.00$ & $0.20 \pm 0.02$ & - \\
Second Floor & Before washing & $10.00 \pm 0.12$ & $8.00 \pm 0.10$ & $12.00 \pm 0.14$ \\
& After washing & $0.20 \pm 0.02$ & $0.40 \pm 0.00$ & - \\
\hline p-value & (before-after washing) & 0.049 & 0.030 & 0.048 \\
\hline
\end{tabular}

Values are mean \pm S.E. of 2 replicates

\section{OCCURRENCE PERCENTAGE OF FUNGAL ISOLATES BEFORE WASHING OF THE BATHROOMS}

Table 2 shows the frequency of occurrence of the fungal isolates from the walls of the bathrooms. Candida albicans was predominantly isolated (23.40\%) from the ground floor, Aspergillus nidulans was the most frequently isolated fungi (55.56\%) from the first floor and Mucor mucedo was the most frequently occurring fungi from the second floor. The ground floor had more isolated fungal species than the other floors of the hostel. 
Table 2: Occurrence percentage of fungal isolates before washing of the bathrooms

\begin{tabular}{llll}
\hline Fungal isolates & Ground floor (\%) & First floor (\%) & Second floor (\%) \\
\hline Mucor mucedo & 12.77 & nil & 56.00 \\
Candida albicans & 23.40 & 5.56 & Nil \\
Penicillium cyclopium & 21.40 & 22.22 & 8.00 \\
Penicillium oxalicum & 14.89 & nil & 12.00 \\
Aspergillus nidulans & 8.51 & 55.56 & 20.00 \\
Aspergillus niger & 6.38 & 5.56 & Nil \\
Aspergillus flavus & Nil & 11.11 & 4.00 \\
Aspergillus tamari & 4.26 & nil & Nil \\
Trichophyton rubrum & 4.26 & nil & Nil \\
Rhodotorulaspp. & 4.26 & nil & Nil \\
\hline
\end{tabular}

\section{OCCURRENCE PERCENTAGE OF FUNGAL ISOLATES FROM FIRST WEEK}

Figure 1 shows the occurrence percentages of the fungi isolated at the first sample collection. Ten fungal isolates were identified of which Muсоr mucedo occurred most (22.22\%). Other isolates include; Aspergillus nidulans (21.11\%), Penicillium cyclopium (17.78\%), Candida albicans (13.33\%), P. oxalicum (11.11\%), A. niger(4.44\%), A. flavus (3.33\%), A. tamari (2.22\%), Trichophyton rubrum (2.22\%) and Rhodotorula species (2.22\%). 


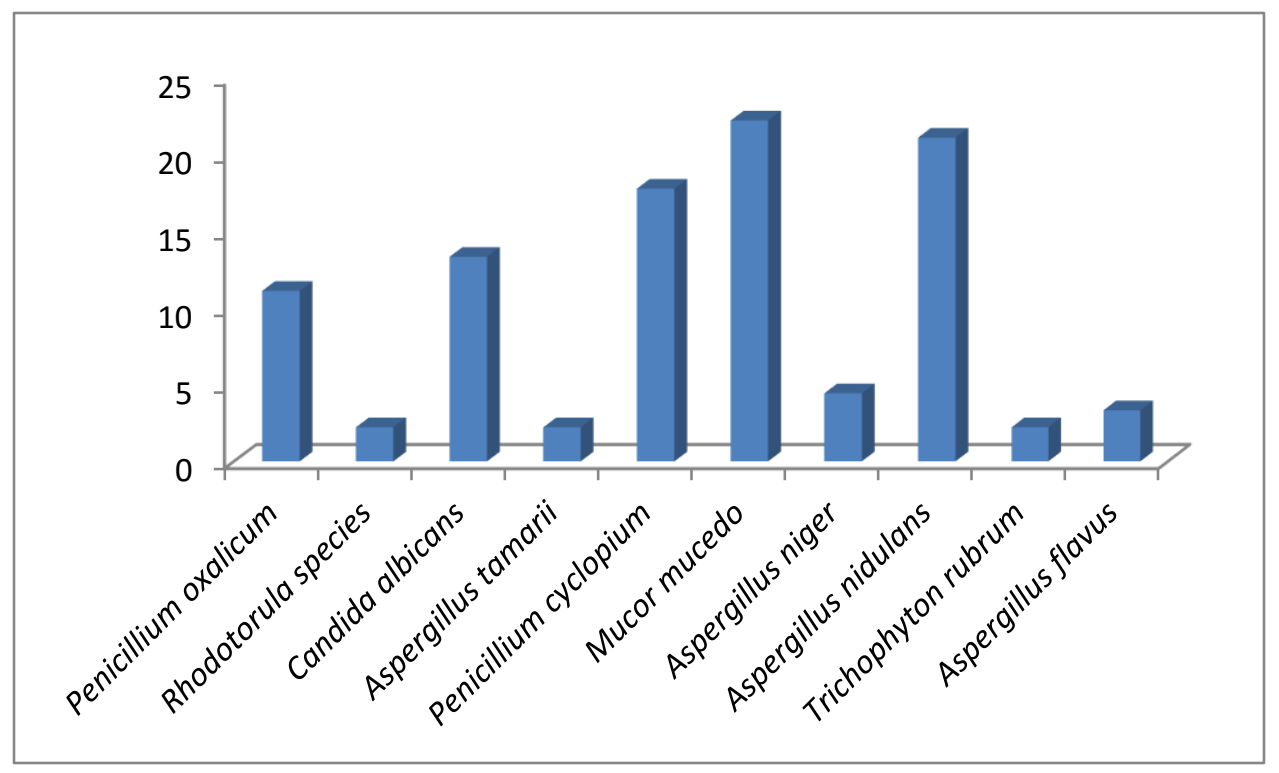

Figure 1: Occurrence percentage of fungal isolates from first week

\section{OCCURRENCE PERCENTAGE OF FUNGAL ISOLATES FROM SECOND WEEK}

Figure 2 shows the occurrence percentages of the fungi isolated at the second sample collection. Seven fungal isolates were identified of which Candida albicans occurred most (25.97\%). Penicillium cyclopium (19.48\%), Mucor mucedo (18.18\%), Aspergillus nidulans (18.18\%), P. oxalicum (9.09\%), A. niger (5.19\%) and A. flavus (3.90\%) were also isolated.

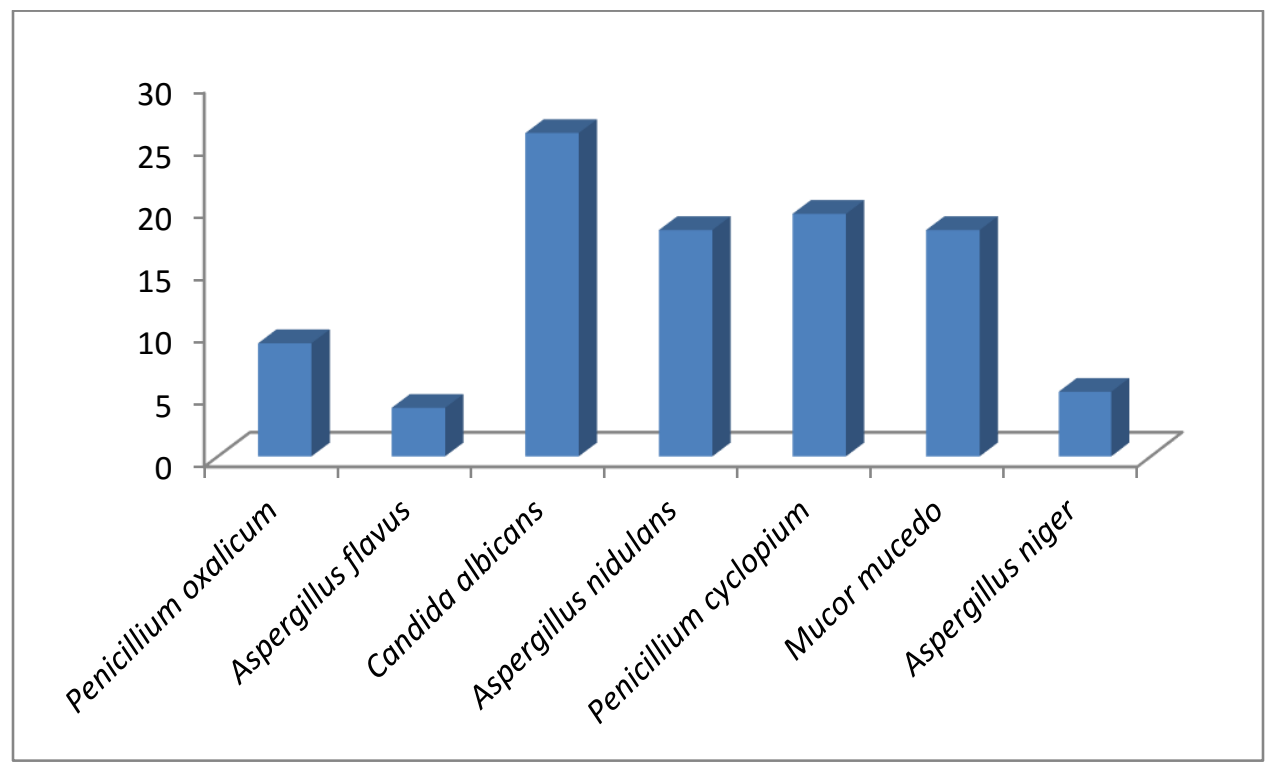

Figure 2: Occurrence percentage of fungal isolates from second week 


\section{OCCURRENCE PERCENTAGE OF FUNGAL ISOLATES FROM THIRD WEEK}

Figure 3 shows the occurrence percentages of the fungi isolated at the third sample collection. Ten fungal isolates were identified of which Muсоr mисеdo occurred most (25.24\%). Other fungi isolated include: Aspergillus nidulans (23.30\%), Penicillium cyclopium (16.51\%), P. oxalicum (12.62\%), Candida albicans (3.88\%), Rhodotorula species (3.88\%), A. niger (3.88\%) A. tamarii (3.88\%), Trichophyton rubrum (3.88\%), and A. flavus (2.91\%) were also isolated.

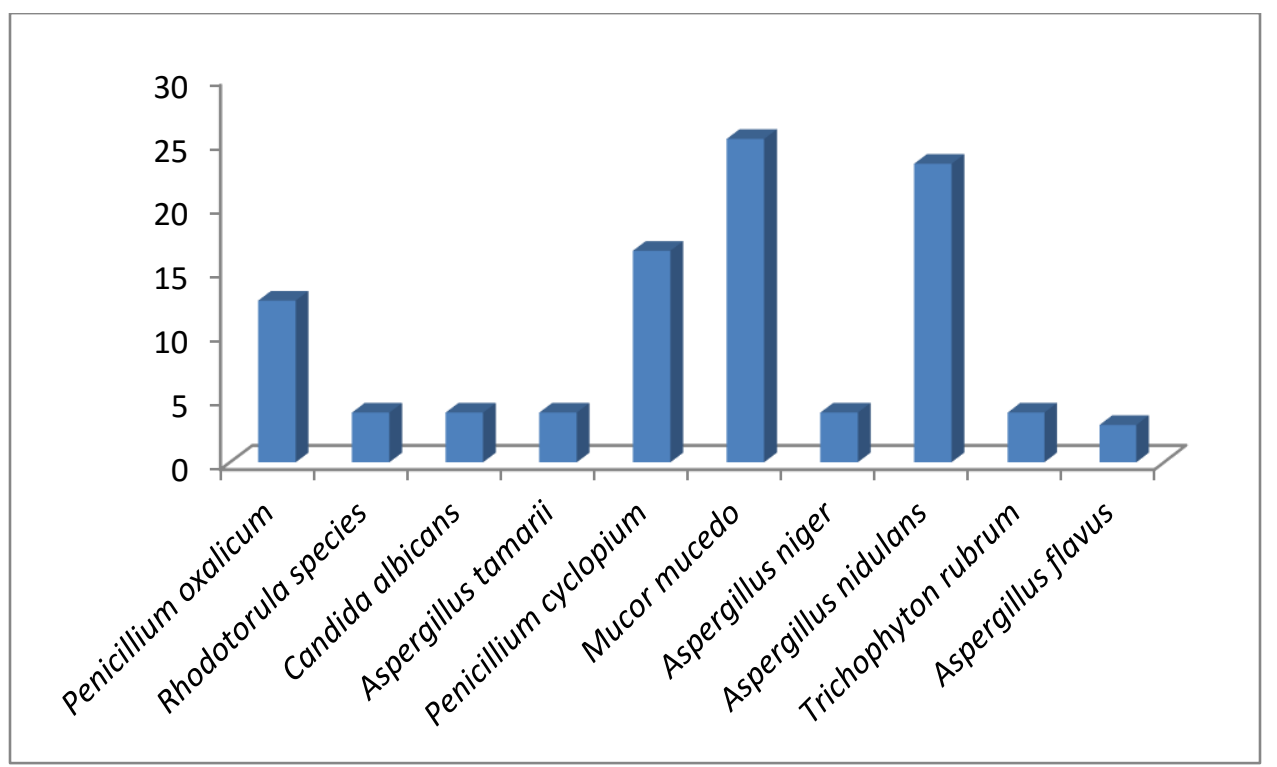

Figure 3: Occurrence percentage of fungal isolates from third week

\section{DISCUSSION}

Mould and yeast contamination are higher in the upper part of bathrooms (Hamada, 2004) and the frequency of cleaning bathrooms' floors with detergents and disinfectants is much higher than that of the upper parts of the bathrooms, hence the prevalence of fungi on the walls of such bathrooms. This has led to the study of bathrooms' walls in highly populated (school) environment, for the presence of fungal growth.

Results from Table 1 shows that the highest prevalence of fungi was from the ground floor bathroom. Consistent observations by the ground floor occupants revealed that there was regular usage of the bathroom by passers-by who tend to ease themselves at the ground floor hence increasing the microbial loads by the introduction of foot wears and urine (Ayanbimpe et al., 2012) into the bathroom. The ground floor had the highest fungal count, while the first floor had the least fungal count. Before washing of the bathrooms, the fungal count $\left(x 10^{4} \mathrm{cfu} / \mathrm{cm}^{2}\right)$ ranged between $6.40 \pm 0.04$ and $22.80 \pm 0.30$, while after washing the fungal count $\left(x 10^{4} \mathrm{cfu}^{\mathrm{c}} \mathrm{cm}^{2}\right)$ ranged from 0.00 \pm 0.00 to $0.80 \pm 0.02$. Fungal isolates of the species Мисог mисеdo was only isolated and identified after washing of the bathrooms. There was a significant reduction of the fungal loads on the first week $(\mathrm{p}=0.049)$, second week $(\mathrm{p}=$ $0.030)$ and third week $(\mathrm{p}=0.048)$ in the hostel, after cleaning of the bathrooms. 
Results from Table 2 shows that Candida albicans had the highest prevalence (23.40\%) in the ground floor's bathroom, the first floor was mostly contaminated with Aspergillus nidulans (55.56\%), while the second floor had Mucor mисеdo $(56.00 \%)$ as its most occurring fungal isolate. The high prevalence of Candida albicans on the ground floor could be as a result of the regular abuse of the bathroom by passers-by, who tend to urinate there. Candida albicans is the most commonly reported species in urine culture (Gajdacs et al., 2019). According to the study carried out by Jabber et al., 2016, Candida albicans had the highest occurrence percentage in the female bathrooms in Thi-Qar Government. The high prevalence of Mucor mucedo on the second floor could be as a result of the dispersal of the bio-particles such as its spores and plant parts by wind (Singh, 2017) from the outdoor to the indoor environment through the windows and door.

Results from Figure 1 and Figure 3 shows that Mисоr mисеdo had the highest occurrence percentage of $22.22 \%$ and $25.24 \%$, at the first and third week of the study respectively. Figure 2 shows that at the second week of fungal enumeration of the bathrooms' walls, Candida albicans had the highest occurrence percentage of $25.97 \%$. The fungal counts from the hostel bathrooms may had reduced due to the lysing effect of detergents and disinfectants. The bathrooms seldom harbor Mucor mucedo when not properly washed, which still pose a threat to human health. Quan and Spellberg (2010) stated that mucormycosis pneumonia has a higher mortality rate than that of most other pathogenic fungi. Thorough cleaning of bathrooms with biocides such as detergents and disinfectants destroy the cell walls of microorganisms and interfere with their growth and metabolism. However, disinfectants can be sporostatic but not necessarily sporicidal (McDonnell and Russell, 2001).

\section{CONCLUSION}

Fungal occurrence in the bathrooms reduced after washing with detergents and disinfectants. The opportunistic fungi could be inhaled by students and exacerbate asthmatic attacks, pneumonia and other illnesses. The isolated fungi which are of public health significance, are known to cause aspergillosis, vaginal candidiasis, keratitis and otomycosis. Hence, strict hygiene practices should be observed by those using the bathrooms. Cleaning of bathrooms should be regularly and thoroughly done with detergent and disinfectant solutions.

\section{ACKNOWLEDGEMENT}

All glory and thanks be to God Almighty whose grace and love never cease and who establishes the works of our hands. Gratitude to the Organization for Women in Science for the Developing World (OWSD) for the opportunity given to present this research work in their annual conference and to the African Journal of Health, Safety and Environment (AJHSE) for the publication of this work. Appreciation also goes to the authors of the references and other literatures referred to in this research work.

\section{CONFLICT OF INTEREST}

The authors declare that there is no conflict of interest in this research work. 


\section{REFERENCES}

Ahiamba J. E., Dimuna, K. O. and Okogun, G. R. A. (2008). Built environment decay and urban health in Nigeria. Journal of Human Ecology, 23(3): 259-265. doi:10.1080/09709274.2008.11906079.

Al-Mohanna, M. T. (2016). Methods for fungal enumeration, isolation and identification. Research Gate, $155-241$. doi:10.13140/RG.2.2.12515.96809.

Arora, D. R., Saini, S., Aparna and Gupta, N. (2003). Evaluation of germ tube test in various media. Indian Journal of Pathology and Microbiology, 46(1): 124-126.

Ayanbimpe, G. M., Wapwera, S. D. and Kuchin, D. (2010). Indoor air mycoflora of residential dwellings in Jos metropolis. African Health Sciences, 10(2): 172-176.

Ayanbimpe, G.M., Danjuma, W.S. and Okolo, M.O. (2012). Relationship between fungal contamination of indoor air and health problems of some residents in Jos. Research Gate, 18pp. doi:10.5772/32160.

Bueno, D. J. and Silva, J. O. (2014). The Fungal Hypha. In: Batt, C. A. and Tortorello, M. L. (Eds.), Encyclopedia of Food Microbiology, Second Edition. Elsevier Limited, Academic Press, pp 11-19. doi:10.1016/B978-0-12-384730-0.00132-4.

Caillaud, D., Leynaert, B, Keirsbulck, M. and Nadif, R. (2018). Indoor mould exposure, asthma and rhinitis: findings from systematic reviews and recent longitudinal studies. European Respiratory Review, 27(148): 170137 . doi:10.1183/16000617.0137-2017.

Carris, L. M., Little, C. R. and Stiles, C. M. (2012). Introduction to Fungi. The Plant Health Instructor. American Phytopathological Society http://www.apsnet.org/edcenter/intropp/PathogenGroups/Pages/IntroFungi.aspx.

Catherine, K., Budambula, N.L.M., Okoth, S., Kagali, R. and Matiru, V. (2015). Cultural characterization of fungi isolated from oil contaminated soils. Journal of Biology, Agriculture and Healthcare, 5(16): 16-21.

Cheesebrough, M. (2006). District laboratory practice in tropical countries Part 2. London Cambridge University Press, United Kingdom, 442pp.

Crook, B. and Burton, N. C. (2010). Indoor moulds, sick building syndrome and building related illness. Fungal Biology Reviews, 24(3): 106-113. doi: 10.1016/j.fbr.2010.05.001.

DeHoog, G. S., Guarro, J., Gene, J. and Figueras M. J. (2004). Atlas of Clinical Fungi. Atlas Version 2004.1, CD realization by Weniger, T. Computer Science ii University of Wurzburg Germany. 
Food and Agricultural Organization (FAO). (2006). Handbook of mycological methods. Fiat Panis 33pp. http://www.fao.org/fileadmin/user_upload/agns/pdf/coffee/Annex-F.2.pdf.

Gajdacs, M., Doczi, I., Abrok, M., Lazar, A. and Burian, K. (2019). Epidemiology of candiduria and Candida urinary tract infections in inpatients and outpatients: results from a 10 -year retrospective survey. Central European Journal of Urology, 72(2): 209-214. doi: 10.5173/ceju.2019.1909.

Hamada, N. (2004). Dirt suspended in washing water and mould contamination. Journal of Urban Living and Health Association, 48(3): 124-130. doi:10.11468/seikatsueisei.48.124.

Jabber, A.S., Abbas, F.N., Abid, I.N., Qasim, M.T., Radhi, L.Y. and Hamim, S.S. (2016). Indoor air study of fungi contamination at internal departments for students in Thi-Qar Government. European Journal of Pharmaceutical and Medical Research, 3(6): 7-12.

Kidd, S., Halliday, C., Alexiou, H. and Ellis, D. (2016). Descriptions of Medical Fungi. Third Edition. Newstyle Printing, Mile End, South Australia 5031.

McDonnell, G. and Russell, A. D. (2001). Antiseptics and Disinfectants: Activity, Action and Resistance. Clinical Microbiology Reviews, 14(1): 227pp. doi:10.1128/CMR.12.1.147.

Mirabelli, M. C., Wing, S., Marshall, S. W. and Wilkosky, T. C. (2006). Asthma symptoms among adolescents who attend public schools that are located near confined swine feeding operations. Paediatrics, 118(1): 66-75. doi:10.1542/peds.2005-2812.

O’Connor, G. T., Walter, M., Mitchell, H., Kattan, M., Morgan, W. J., Gruchalla R. S., Pongracic, J. A., Smartt, E., Stout, J. W., Evans, R., Crain, E. F. and Burge, H. A. (2004). Airborne fungi in homes of children with asthma in low-income urban communities: The Inner-City asthma study. Journal of Allergy and Clinical Immunology, 114(3): 599-606.

Odds, F.C. (1992). Sabouraud ('s) agar. Journal Medical and Veterinary Mycology, 29: 355-359. doi:10.1080/02681219180000581.PMID:1815027.

Ogbeibu, A.E. (2014). Biostatistics: A practical approach to research and data handling. Second edition. Minded Publishing Company Limited, Ugbowo, P.O. Box 5089, Benin City, Nigeria. 285pp.

Public Health England (PHE). (2017). Detection and enumeration of bacteria in swabs and other environmental samples. National Infection Service, Food, Water and Environmental Microbiology Standard Method 22pp. Retrieved on 23rd May, 2017 from: http://www.gov.uk/phe.

Satyada, R. and Sandle, T. (2016). Releasing capacity of pre-sterile cotton swabs for discharging sampled microorganisms. European Journal of Parenteral \& Pharmaceutical Sciences, 21(4):121-127. 
Shenassa, E. D., Liebhaber, A., Daskalakis, C., Braubach, M. and Brown M. (2007). Dampness and mould in the home and depression: An Examination of Mold-Related Illness and Perceived Control of One's Home as Possible Depression Pathways. American Journal of Public Health, 97(10): 1893-1899.

Singh, A. B. (2017). Glimpse of clinical aerobiology in India: an overview. Global Journal of Otolaryngology, 12(3): 555-840. doi: 10.19080/GJO.2017.12.555840.

Straus, D. C. and Wilson, S. C. (2006). Respiratory trichothecene mycotoxins can be demonstrated in the air of Stachybotryschartarum contaminated buildings. Journal of Allergy and Clinical Immunology, 118(3): 767-768. doi:10.1016/j.jaci.2006.06.025. PMID:16950300.

Quan, C. and Spellberg, B. (2010). Mucormycosis, pseudodallescheriasis and other uncommon mould infections. Proceedings of the American Thoracic Society, 7(3): 210-215. doi: 10.1513/pats.200906-033AL.PMID: 20463250 ; PMCID: PMC3266012.

Robins, C. and Morell J. (2007). Mold Housing and Wood. In: Western Wood Products Association 2007. Available from: Â@ 2007 Western Wood Products Association.

Sean, P. and Abbot, P. D. (2002). Mycotoxins and indoor moulds. Indoor Environment Connections, 3(4): 14-24.

U.S. Environmental Protection Agency (2003). An Introduction to Indoor Air Quality (IAQ). Biological Pollutants. Accessed, April 2011. 